\title{
EDITORIAL
}

\section{THE DENTAL OFFICERS ${ }^{\prime}$ ROLE IN A DISASTER SITUATION}

THE 62nd Annual. World Dental Congress was held in London in September 1974 at the Royal Festival Hall. As part of the Congress an International Military Conference was organised by the Commission on Armed Forces Dental Services of the Federation Dentaire Internationale under the chairmanship of Brigadier E. D. Stanhope, Late Royal Army Dental Corps.

The subject of the Military Conference was "The Dental Officers' Role 'in a Disaster Situation". This important theme aroused a widespread interest which was reflected by the attendance of a large audience from some 24 countries.

The speakers were chosen from the three Dental Services of the United Kingdom. The Army presentation by Major J. D. Fleet, Royal Army Dental Corps is published in this issue by courtesy of Professor F. E. Lawton, Editor of the International Dental Journal, to whom due acknowledgement is made.

\section{- THE MILLBANK PIGEONS}

At the beginning of 1940 following our return after five years in Malta we lived for a short period in the Headquarter Mess. Our stay was chiefly memorable because we fell a victim to the (then) unpatriotic plague of German Measles. Thanks to the kindness of the Commandant Colonel F. Irvine we were not carted off to the local lazar house but were permitted to remain in our room.

During the period of our incarceration time hung heavy on our hands as apart from one daily paper we had no reading material. However we did contrive to while away the time-mainly in two ways. We had a tin of brown boot polish and with the handle of an old tooth brush we boned our Sam Browne until it gleamed like a newly shelled chest-nut. Our second occupation was in watching the love life of George and Georgina - two wood pigeons who nested on one of the window ledges of our room. Probably because we knew them so well in our native land, and because of the charming highland belief that anyone seriously ill would recover if nursed on a mattress filled with dove's feathers, we have always been fond of wood pigeons.

George and Georgina proved to be a delightful pair of lovers who in turn were the most conscientious of parents. In the fullness of time they successfully reared their nest-full of young and flew off to fresh scenes.

We too in the fullness of time departed from Millbank with our happy memories of the pigeons and our precious Sam Browne (now we are pleased to report sold on behalf of Corps funds and still serving às an ornament to our Corps).

Some five years ago we returned to Millbank to work in the Muniment Room where amidst our other activities we edit the Journal. We were pleased to note that on a lédge of pipes below our room the present generation of George and Georgina nested and did so each year until a couple of seasons ago when owing to the renewal of the central heating with smaller pipes, the ledge vanished. Another Temple gone. May we assure our readers that our Millbank pigeons are still with us and still nesting. Long may this last, as their charming coos and calls to each other make City life so much more endurable and to us at Millbank would not be Millbank without them. 